Hal: 9 - 14

\title{
SINTASAN IKAN MUJAIR (Oreochromis mossambicus) YANG DIPELIHARA PADA TAMBAK AIR PAYAU DENGAN PEMBERIAN FREKUENSI PAKAN ALAMI KLEKAP BERBEDA
}

\author{
KHAIRUL \\ Dosen Program Studi Pendidikan Biologi STKIP Labuhan Batu \\ Email:khairul_spi@yahoo.com
}

Diterima Maret 2018 dan Disetujui Mei 2018

\begin{abstract}
ABSTRAK
Ikan mujair merupakan salah satu jenis ikan budidaya air tawar. Umumnya ikan ini dipelihara di dalam kolam, sawah, sungai dan danau. Namun bisa pula dipelihara di tambak yang berair payau, karena sifatnya yang euryhaline. Harganya di Belawan mencapai Rp. $35.000-40.000$ per kilo untuk ukuran 4-5 ekor. Belakangan ini ikan mujair mulai jarang dijumpai dijual dipasar. Diduga karena pembudidaya sekarang merasa malas memelihara ikan ini karena terkendala oleh biaya pakan yang mahal. Selama ini masyarakat hanya mengandalkan pakan komersial (pellet).selama proses produksi. Pemanfaatan pakan alami selama ini belum dioptimalkan, padahal ketersediannya di alam melimpah. Pada tambak-tambak air payau banyak dijumpai pakan alami klekap ini. Beberapa jenis ikan sangat menyukai klekap, diantaranya ikan bandeng, belanak, ketang, baronang termasuk ikan mujair. Penelitian ini bertujuan untuk mengetahui sintasan (Survival Rate $=\mathrm{SR}$ ) benih ikan mujair yang dipelihara di tambak air payau dengan diberikan pakan alami berupa klekap. Diharapkan dari hasil penelitian dapat dijadikan pedoman bagi masyarakat yang membudidayakan ikan mujair untuk memanfaatkan pakan alami yang tersedia. Hal ini untuk mengurangi beban operasional yang hampir $70 \%$ dari biaya pakan. Hasil penelitian menunjukan sintasan ikan mujair tertinggi pada perlakuan $D$ $(91,33 \%)$, perlakuan C $(82,33 \%)$, Perlakuan B $(70,67 \%)$ dan yang terendah Perlakuan A $(65 \%)$. Hasil analisis variansi menunjukkan $\mathrm{Fh}\left(64,24^{* *}\right)>\mathrm{Ft} 0,01(7,59)$ berarti perlakuan berpengaruh sangat nyata. Hal ini berarti Ha diterima dan Ho ditolak.
\end{abstract}

Keyword: pakan alami klekap, ikan mujair, sintasan

\section{PENDAHULUAN}

Ikan mujair sebenarnya ikan domestikasi yang berasal dari perairan Afrika dan pertama kali ditemukan di Indonesia di muara sungai Serang pantai selatan Blitar Jawa Timur pada tahun 1939 (Afandi 1992). Ikan ini memang sekilas mirip dengan ikan nila. Namun secara morfologi berbeda, walapun masih satu genus.

Masyarakat umumnya memelihara ikan mujair di kolam air tawar, sungai, sawah, dan danau. Namun ikan ini bisa juga dipelihara pada tambak yang berair payau. Hal ini karena ikan ini mampu mentolerasi interval salinitas yang berbeda (termasuk ikan euryhaline). Ikan mujair dapat hidup pada perairan yang memiliki kadar garam/ salinitas sampai $35 \mathrm{ppm}$ (Harahap, 2014). Di daerah sekitar Belawan ikan ini sering masuk ke dalam tambak sebagai ikan liar. Acap kali ketika masyarakat memelihara udang windu, ikan mujair mereka anggap sebagai hama penggangu (kompetitor) karena biasanya akan memakan pakan udang yang diberikan. Bagi para pembudidaya udang biasanya akan membasmi ikan mujair dengan menggunakan saponin.

Ikan mujair sebenarnya ikan yang mempunyai nilai ekonomis sedang dan disukai masyarakat. Sering menjadi menu rumah makan sebagai ikan bakar dan gulai. Rasanya yang gurih sehingga menjadi menu favorit pelanggan. Saat ini harga ikan mujair di Belawan rata-rata berkisar antara Rp. 35.000 - 40.000,- untuk ukuran 4 - 5 ekor per kilo.

Selama pemeliharaan ikan mujair para pembudidaya biasa memberikan pakan berupa pellet komersial. Di dalam memacu produkivitas dan pertumbuhan ikan, maka diberikan makanan tambahan dengan komposisi sebagai berikut: tepung ikan $25 \%$, tepung kopra $10 \%$ dan dedak halus sebesar $65 \%$. Komposisi ransum ini digunakan dalam usaha budidaya ikan mujair secara komersial. Namun dapat juga 
diberi makanan yang berupa pellet yang berkadar protein $20-30 \%$ dengan dosis 2 $3 \%$ dari berat populasi per hari, diberikan sebanyak 2 kali/ hari yaitu pada pagi dan sore hari (Prihatman, 2000). Seiring dengan meningkatnya harga pakan masyarakat menjadi malas membudidayakan ikan mujair. Pakan yang mahal menjadi beban tersendiri bagi pembudidaya. Biaya operasional bisa mencapai $70 \%$ yakni berasal dari pakan.

Pakan alami harus menjadi alternatif agar usaha budidaya bisa terus berjalan. Pemanfaatan pakan alami untuk menekan biaya produksi yang berasal dari pakan komersial. Ada berbagai jenis pakan alami yang biasanya tumbuh di tambak. Salah satunya adalah klekap. Beberapa jenis ikan menyukai klekap seperti bandeng, belanak, ketang, baronang dan mujair. Klekap terdiri dari berbagai organisme penyusun, baik fitoplankton maupun zooplankton. Berdasarkan hasil penelitian Suwono dkk (2016) diketahui jenis plankton penyusun klekap terdiri atas fitoplankton dan zooplankton. Jumlah jenis dan individu fitoplankton didapatkan lebih besar dibandingkan dengan zooplankton. Persentasi kelas tertinggi didapatkan pada kelas Cyanophyceae sebanyak 71,8\%; kemudian Bacillariophyceae sebanyak 17,8\%; selanjutnya Crustacea 5,0\%; Rotatoria 2,9\%; Dyanophyceae 2,2\%; dan Polychaeta 0,2\%.

Berdasarkan komposisi beberapa jenis plankton dan zooplankton tersebut, maka klekap sangat cocok untuk dijadikan sebagai pakan alami bagi ikan. Penentuan pakan yang tepat pada pemeliharaan stadia benih tentunya akan turut meningkatkan keberhasilan. Kita ketahui bersama bahwa pakan merupakan salah satu faktor pembatas bagi kehidupan ikan.

Pakan sebagai faktor pembatas (limiting factor) sangat menentukan kelulushidupan (sintasan) pada ikan yang dipelihara. Hal ini sangat berhubungan erat produksi yang dihasilkan, karena jika sintasan ikan rendah maka tentunya produksi juga rendah, begitu sebaliknya jika sintasn tinggi produksi yang akan dihasilkan juga tinggi.

Penelitian penggunaan biomassa klekap yang dilakukan Suwono dkk (2016) menunjukan sintasan nener bandeng pada perlakuan pupuk yang berbeda berkisar antara $86,7 \%$ - 100\%. Namun untuk penelitian terhadap ikan mujair belum ada yang melakukan.

\section{METODE PENELITIAN \\ Waktu dan Tempat}

Penelitian ini dilakukan pada bulan Januari sampai bulan Februari 2018. Tempat penelitian di Lingkungan 20 Kelurahan Belawan Sicanang kecamatan Medan Belawan Kota Medan Provinsi Sumatera Utara.

\section{Bahan dan Alat}

Bahan Penelitian yang digunakan adalah benih ikan mujair ukuran $2-3 \mathrm{~cm}$ sebanyak 1200 ekor dan media pemeliharaan adalah tambak air payau. Alat-alat yang digunakan untuk mengukur kualitas air pada penelitian ini adalah termometer untuk mengukur suhu, $\mathrm{pH}$ meter untuk mengukur $\mathrm{pH}$ air, DO meter untuk mengukur oksigen terlarut/ Disolved Oxygen (DO).

\section{Wadah Penelitian}

Wadah pemeliharaan ikan yang digunakan pada penelitian ini berupa waring. Adapun ukuran waring yang digunakan adalah 1 meter $\times 1$ meter $\times 1$ meter sebanyak 12 petak. Waring kemudian diletakan pada tambak air payau (20 ppt) dengan ukuran luas tambak 5.000 meter persegi

\section{Jenis Penelitian}

Penelitian ini merupakan penelitian eksperimen yakni dengan jalan melakukan ujicoba langsung di lapangan. Penelitian ini menggunakan kontrol dan 3 taraf perlakuan dan untuk masing-masing perlakuan diberi 3 kali ulangan. Adapun perlakuan dalam penelitian ini adalah sebagai berikut:

1. Perlakuan A : Kontrol (diberi pakan pellet komersial secara at libitum)

2. Perlakuan B : Frekuensi pemberian pakan klekap 1 kali perhari

3. Perlakuan $\mathrm{C}$ : Frekuensi pemberian pakan klekap 2 kali perhari

4. Perlakuan D : Frekuensi pemberian pakan klekap 3 kali perhari

\section{Prosedur Penelitian}

Penentuan tata letak wadah
penelitian dilakukan pengacakan. Benih ikan sebelum ditebar dilakukan aklimatisasi terlebih dahulu. Memasukan benih ikan sebanyak 100 ekor pada tiap-tiap wadah. Pemberian pakan 
dilakukan setelah 1 hari benih ikan ditebar dan diberikan sesuai taraf perlakuan yang dilakukan, namun untuk perlakuan kontrol diberikan pakan pelet komersial secara at libitum. Pengukuran kualitas air dilakukan seminggu sekali untuk mengecek suhu, $\mathrm{pH}$, dan DO. Setelah 30 hari masa pemeliharaan ikan maka dilakukan pengukuran pertumbuhannya. Selajutnya melakukan tabulasi dan analisis data. Langkah terakhir adalah membuat laporan penelitian.

\section{Pengamatan dan Pengumpulan Data Sintasan (Survival Rate)}

Sintasan ikan dapat diketahui dengan menggunakan rumus Effendie (1997) sebagai berikut :

$$
S R=\frac{N t}{N o} x 100 \%
$$

dimana: SR = Survival Rate (\%); No = Populasi awal (ekor); Nt = Populasi akhir (ekor)

\section{Pengamatan Kualitas Air}

Pengukuran parameter kualitas air yang dilakukan meliputi: suhu, $\mathrm{pH}$, dan $\mathrm{DO}$.

\section{Analisis data}

Analisi data dilakukan dengan Analisis Variansi (Anava) menurut rumus Sastrosupadi (2000) adalah sebagai berikut

$$
Y_{i j}: \mu+T_{i}+\varepsilon i j
$$

Keterangan:

$Y_{i j}=$ data yang disebabkan pengaruh pemberian frekuensi ke $\mathrm{i}$ ulangan $\mathrm{ke}-\mathrm{j} ; \mu$ $=$ pengaruh rata-rata umum $; \mathrm{T}_{i}=$ efek yang sebenarnya dari perlakuan pada taraf ke- $\mathrm{i}$; $\varepsilon_{\mathrm{ij}}=$ efek error dari perlakuan taraf ke $-\mathrm{i}$ dan ulangan ke - j

Selanjutnya untuk mengetahui diterima tidaknya hipotesis yang diajukan maka dilakukan uji statistik. Menurut Bangun (1991) yakni dengan menggunakan uji $F$ dengan membandingkan nilai $F$ hitung $(\mathrm{Fh})$ dengan $\mathrm{F}$ tabel $(\mathrm{Ft})$ pada taraf nyata 0,05 dan 0,01

\section{HASIL DAN PEMBAHASAN Sintasan (Survival Rate)}

Setelah 30 hari masa pemeliharaan maka dilakukan penghitungan sintasan ikan. Selanjutnya data sintasan ikan selengkapnya dapat dilihat pada Gambar 1. di bawah ini:

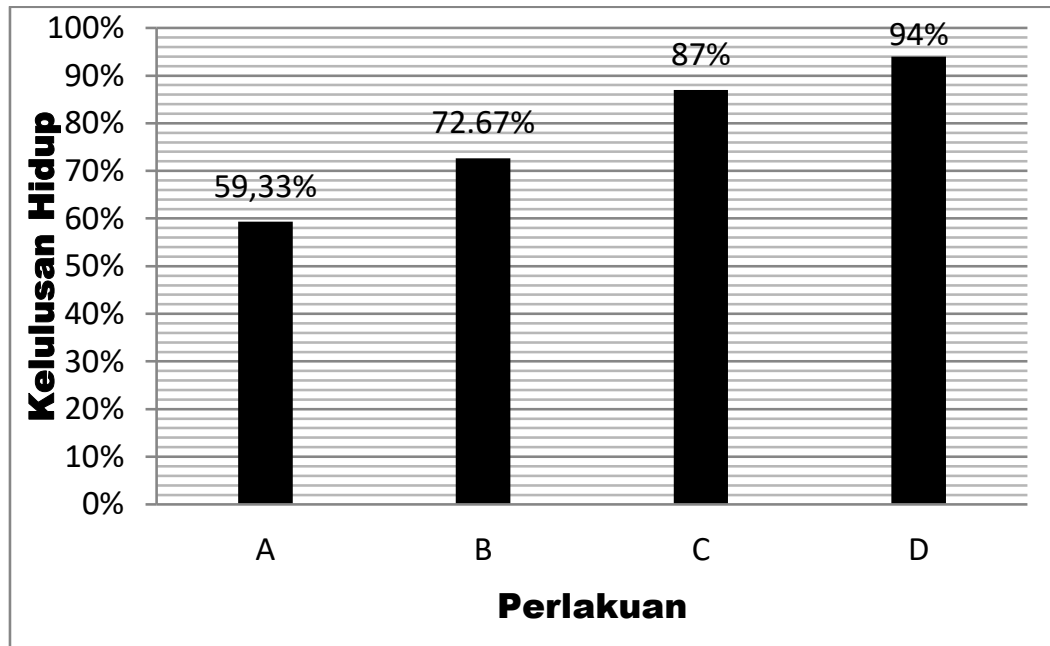

Gambar 1. Histogram rata-rata sintasan Ikan mujair untuk setiap perlakuan

Berdasarkan hasil penelitian yang dilakukan diperoleh sintasan benih ikan mujair tertinggi yakni pada perlakuan $D$ (94\%), kemudian diikuti perlakuan B (87\%), dan perlakuan $C(72,67 \%)$ serta yang terendah pada perlakuan A $(59,33 \%)$. Hal ini diduga karena kecukupan pakan yang diberikan yang mampu meningkatkan sintasan benih ikan. Ikan yang dipelihara pada media terkontrol membutuhkan pakan untuk kelangsungan hidup dan pertumbuhannya. 
Pakan yang diberikan merupakan salah satu faktor pembatas (limiting factor) bagi kehidupan ikan. Menurut Watanabe (1998) kelulusan hidup ikan tergantung faktor biotik dan abiotik. Faktor biotik terdiri dari umur dan kemampuan ikan dalam beradaptasi terhadap lingkungan. Faktor abiotik antara lain ketersediaan makanan dan kualitas air media. Selajutnya Diansari dkk (2013) menjelaskan makanan yang dimakan oleh ikan pertama-tama digunakan untuk kelangsungan hidup dan apabila lebih maka kelebihanya baru dimanfaatkan untuk pertumbuhan.

Kajian tentang kelulusan hidup ikan mujair pernah dilakukan oleh Suyantri dkk (2011) Survival Rate ikan mujair di Kali Mas Surabaya berkisar antara 6,67 - 45\% dalam rentang waktu 28 hari. Angka Survival Rate yang paling tinggi paling tinggi berada di daerah yang mewakili hulu (Gunung Sari) sebesar 45\% dan yang paling rendah berada di daerah hilir (Petekan) sebesar 6,67\%. Kelulusan hidup ikan mujair tersebut jauh lebih rendah bila dibandingkan dengan hasil penelitian ini.

Diketahui adanya kematian ikan pada saat penelitian setelah diamati, terjadi pada 1 minggu pertama, karena ikan pada saat itu banyak yang tidak makan sehingga menyebabkan ikan lemas dan kemudian mati. Ikan saat itu masih melakukan proses adatasi terhadap pakan yang diberikan sehingga awalnya ikan banyak yang tidak makan terutama pada Perlakuan A (Kontrol = diberi pakan pellet komersial). Namun pada perlakuan D, C dan B ikan lebih cepat beradaptasi terhadap pakan yang diberikan dan langsung memakannya. Diduga pakan alami klekap yang diberikan memiliki aroma yang khas sehingga lebih cepat direspon oleh ikan.

Berdasarkan hasil analisis variansi (ANOVA) menunjukkan bahwa Fh $\left(12,59^{* *}\right)$ $>$ Ft $0,01(7,59)$ berarti perlakuan frekuensi pemberian pakan alami klekap berbeda berpengaruh sangat nyata (Highly Significant) terhadap sintasan benih ikan mujair. Hal ini berarti $\mathrm{Ho}$ ditolak dan $\mathrm{Ha}$ diterima.

\section{Parameter Kualitas Air}

Berdasarkan hasil pengukuran parameter kualitas air maka diperoleh: suhu air rata-rata berkisar $28-30{ }^{\circ} \mathrm{C}, \mathrm{pH}$ air rata-rata berkisar 7,6 - 7,9 dan DO ratarata berkisar antara 3,5-4 ppm Data hasil pengukuran kualitas air selama penelitian selengkapnya dapat dilihat pada Tabel 1 .

Tabel 1. Hasil Pengamatan Rata-rata Parameter Kualitas Air Selama Penelitian.

\begin{tabular}{|c|c|c|c|c|c|c|c|c|c|}
\hline \multirow{3}{*}{ Perlakuan } & \multicolumn{3}{|c|}{ Suhu $\left({ }^{\circ} \mathrm{C}\right)$} & \multicolumn{3}{|c|}{$\mathrm{pH}$ Air } & \multicolumn{3}{|c|}{ DO (ppm) } \\
\hline & \multicolumn{3}{|c|}{ Pukul (WIB) } & \multicolumn{3}{|c|}{ Pukul (WIB) } & \multicolumn{3}{|c|}{ Pukul (WIB) } \\
\hline & $09 .^{\circ 0}$ & $15^{\circ \circ}$ & $21 .^{\circ}$ & $09.9^{\circ}$ & $15^{\circ \circ}$ & $210^{\circ 0}$ & $09 . .^{\circ}$ & $15^{\circ \circ}$ & $21 .^{\circ}$ \\
\hline $\mathrm{A} 1$ & 28 & 29 & 30 & 7,7 & 7,8 & 7,9 & 3,6 & 4,0 & 3,9 \\
\hline A2 & 28 & 29 & 30 & 7,7 & 7,8 & 7,8 & 3,6 & 3,7 & 3,7 \\
\hline A3 & 28 & 29 & 30 & 7,7 & 7,8 & 7,8 & 3,6 & 3,9 & 3,8 \\
\hline B1 & 28 & 28 & 30 & 7,7 & 7,8 & 7,8 & 3,5 & 3,9 & 3,8 \\
\hline B2 & 28 & 29 & 30 & 7,7 & 7,8 & 7,8 & 3,6 & 3,8 & 3,8 \\
\hline B3 & 28 & 29 & 30 & 7,8 & 7,9 & 7,9 & 3,7 & 3,9 & 3,7 \\
\hline C1 & 28 & 29 & 30 & 7,7 & 7,8 & 7,8 & 3,6 & 3,9 & 3,8 \\
\hline C2 & 28 & 29 & 30 & 7,7 & 7,8 & 7,8 & 3,7 & 3,7 & 3,8 \\
\hline C3 & 28 & 29 & 30 & 7,7 & 7,8 & 7,8 & 3,6 & 3,7 & 3,8 \\
\hline D1 & 28 & 29 & 30 & 7,6 & 7,8 & 7,8 & 3,6 & 3,9 & 3,6 \\
\hline D2 & 28 & 29 & 30 & 7,6 & 7,7 & 7,8 & 3,7 & 4,0 & 3,9 \\
\hline D3 & 28 & 28 & 30 & 7,6 & 7,8 & 7,7 & 3,6 & 3,7 & 3,8 \\
\hline
\end{tabular}

Dapat disimpulkan bahwa semua faktor fisik kimia kualitas air yang diukur selama penelitian masih mendukung untuk sintasan benih ikan mujair. Merujuk pada hasil penelitian yang dilakukan Suyantri dkk (2011) suhu yang terukur di perairan Kali Mas Surabaya berkisar antara 27,9 - 29,3
${ }^{\circ} \mathrm{C}$ di stasiun sampling $1,26,4-29,1 \stackrel{\circ}{ } \mathrm{C}$ di stasiun sampling 2 , dan $28,4-30,6 \stackrel{\circ}{\circ}$ di stasiun sampling 3 . Kisaran suhu yang diukur selama penelitian ini merupakan kisaran suhu yang optimal bagi pertumbuhan ikan untuk jenis ikan tropis. 
Suhu akan mempengaruhi aktivitas enzim dimana kenaikan suhu akan menyebabkan penurunan $\mathrm{pH}$ enzim dan pada $\mathrm{pH}$ rendah enzim-enzim pencernaan akan lebih mudah menghancurkan materimamateri kasar yang berasal dari pakan yang dikonsumsi (Taufik dkk, 2009).

Menurut Nana (2011) kondisi pH air optimal untuk ikan adalah pada nilai $\mathrm{pH}$ antara 6,5-8,5. Nilai $\mathrm{pH}$ di atas 9,2 atau kurang dari 4,8 bisa membunuh ikan dan $\mathrm{pH}$ di atas 10,8 dan kurang dari 5,0 akan berakibat fatal bagi kehidupan ikan.

Fujaya (2004) menyatakan bahwa jika rendahnya jumlah oksigen dalam air menyebabkan ikan atau hewan air harus memompa sejumlah besar air ke permukaan alat respirasinya untuk mengambil oksigen. Lebih lanjut menurut Urbasa (2015) kadar oksigen terlarut yang rendah menyebabkan proses penguraian, reproduksi, dan pertumbuhan ikan di dalam kolam tidak berjalan dengan baik. Nilai minimum kadar oksigen terlarut untuk budidaya ikan adalah 3 ppm.

\section{KESIMPULAN DAN SARAN Kesimpulan}

Dapat disimpulkan bahwa apabila frekuensi pemberian pakan alami klekap meningkat, maka sintasan ikan akan tinggi. Berdasarkan hasil uji Anava menunjukan bahwa frekuensi pemberian pakan alami klekap berpengaruh sangat nyata. terhadap sintasan ikan. Selanjutnya hasil pengamatan pengukuran kualitas air diperoleh suhu rata-rata $\left(28-30^{\circ} \mathrm{C}\right), \mathrm{pH}$ air rata-rata $(7,6-7,9)$ dan $\mathrm{DO}$ rata-rata $(3,5$ 4 ppm). Kondisi kualitas air ini masih sangat mendukung sintasan benih ikan.

\section{Saran}

Disarankan kepada pembudidaya untuk memanfaatkan pakan alami sebagai pakan alternatif, sehingga dapat menekan biaya operasional. Perlu dilakukan penelitian lanjutan tentang penggunaan pakan alami berupa kelekap ini terhadap jenis ikan lainnya.

\section{UCAPAN TERIMA KASIH}

Penulis mengucapkan terima kasih yang sebesar-besarnya kepada Bapak Syahdan sebagai ketua Kelompok Budidaya Ikan (Pokdakan) Sukakarya VI yang telah memberikan izin tempat penelitian

\section{DAFTAR PUSTAKA}

Afandi. 1992. Ikhtiologi, Suatu Panduan Kerja Laboratorium. Depdikbud, Institut Pertanian Bogor (IPB), Bogor.

Andayani, Sri. 2012. Pengaruh Kelimpahan Klekap Di Tambak Tradisionl Terhadap Pertumbuhan Ikan Bandeng \& Udang Windiu. Berkala Penelitian Hayati. 17 : 159 - 163

Bangun, M. K. 1991. Rancangan Percobaan. Bagian Biometri. Fakultas Pertanian Universitas Sumatera Utara (USU), Medan

Diansari, RR. Vanya Rhossitha, Endang Ariani dan Tita Elfitasari. 2013. Pengaruh Kepatan Yang Berbeda Terhadap Kelulusan Hidup Dan Pertumbuhan Ikan Nila (Oreochromis niloticus) Pada Sistem Resirkulasi Dengan Filter Zeolit. Journal of Aaquaculture Management and Technology. 2 (3) : 37 - 45.

Effendie, I. 1997. Biologi Perikanan. Yayasan Pustaka Nusatama. Yogyakarta.

Fujiya, Y. 2004. Fisiologi Ikan Dasar Pengembangan Teknik Perikanan. Rineka Cipta, Jakarta.

Harahap, Muhammad Syarif. 2014. Karakteristik Bioakustik dan Tingkah Laku Ikan Mujair (Oreochromis mossambicus) Terhadap Perubahan Salinitas. Skripsi Departemen IImu dan Teknologi Kelautan. Institut Pertanian Bogor (IPB), Bogor.

Jaya, Berian, Fitri Agustriani dan Isnaini. 2013. Laju Pertumbuhan dan Tingkat Kelangsungan Hidup Benih Kakap Putih (Lates calcarifer, Bloch) dengan Pemberian Pakan yang Berbeda. Maspari Journal. 5 (1), 56 - 63. 
Nana, Udi Putra. 2011. Manajemen Kualitas Air Dalam Kegiatan Budidaya Perikanan. Departemen Kelautan dan Perikanan. Direktorat Jendral Perikanan Budidaya. Budidaya Air Payau, Talakar

Sastrosupadi, A. 2000. Rancangan Percobaan. Praktis Bidang Pertanian. Kanisius, Jakarta.

Suyantri, Eni. Aunurohim, dan Nurlita Abdulgani. 2011. Sintasan (Survival Rate) Ikan Mujair (Oreochromis mossambicus) Secara In-Situ Di Kali Mas Surabaya. Artikel IImiah. Jurusan Biologi, Fakultas Matematika dan IImu Pengetahuan Alam. Institut Teknologi Sepuluh November, Surabaya.

Suwoyo, Hidayat Suryanto, Mat Fahrur, Makmur, dan Rachman Syah. 2016. Pemanfaatan Limbah Tambak Udang Super-Intensif Sebagai Pupuk Organik Untuk Pertumbuhan Biomassa Kelekap Dan Nener Bandeng. Media Akuakultur. 11 (2): 97 - 110
Taufik, Imam, Zafril Imran Anwar, dan Sutrisno. 2009. Pengaruh Perbedaan Suhu Air Pada Pemeliharaan Benih Ikan Betutu (Oxyeleotris marmorata Blkr) Dengan Sistem Resirkulasi. Jurnal Riset Akuakultur. Vol. 4, No. 3: 319 - 325.

Urbasa, P.A.. 2015. Dampak Kualitas Air Pada Budi Daya Ikan Dengan Jaring Tancap di Desa Toulimembet Danau Tondano. Jurnal Budidaya Perairan. Vol. 3, No. 1: $59-67$

Prihatman, Kemal. 2000. Budidaya Ikan Mujair (Tilapia mossambica). Proyek Pengembangan Ekonomi Masyarakat Pedesaan BAPPENAS. Jakarta.

Watanabe, T. 1988. Fish Nutrition and Mariculture. Tokyo University of Fisheries. JICA Textbook. The General Aquaculture Course, Tokyo. 